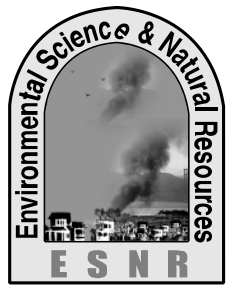

\title{
Prospects of Renewable Energy at Rural Areas in Bangladesh: Policy Analysis
}

\author{
K. M. H. Kabir ${ }^{1}$ and M. K. Uddin ${ }^{2}$
}

${ }^{1}$ Electricity Generation Company of Bangladesh Ltd., Power Division

${ }^{2}$ Department of Environmental Sciences, Jahangirnagar University, Savar

*Corresponding author: as.kabir@gmail.com

\begin{abstract}
Presently the country faces a peak load shortage of $30 \%$ of total demand and the shortage of gas supply resulting in about $10 \%$ of power plants leaving idle. It also reveals that about 1-2\% GDP growth declined annually owing to the shortage of energy and poorer ability of power generation. The present study seeks to analyze the issues and challenges of renewable energy (RE) in Bangladesh with special emphasis on prospects of energy generation at rural areas of Bangladesh and subsequent policy analyses. Electricity generation through RE and implementation of energy efficiency and conservation including the RE policies and their analyses will explore to meet the future unmet demand in power sector. Lessening of dependency on natural gas is one of the top agenda of the government, in addition Bangladesh has enormous prospects of RE (solar energy) to meet the unmet demand particularly at the remote and off grid areas. By this time, the government of Bangladesh has planned to generate $5 \%$ of generation (i.e., $800 \mathrm{MW}$ ) by 2015 and subsequently $10 \%$ (i.e., 2000MW) by 2020 from renewable sources and $20 \%$ of total generation by nuclear, renewable and cross border by 2030 out of 40,000 MW total expected generations. In this paper possible attempts have been made to identify the problems and prospects related to the RE particularly for solar energy at rural areas and their possible recommendations for future development towards achieving millennium goal.
\end{abstract}

Key words: Electricity generation, Off-grid, Policy, Renewable energy

\section{Introduction}

Deployment of renewable energy and energy efficiency including technological diversification would result in significant energy security and economic benefits in Bangladesh. In this regard the government of Bangladesh has planned to generate $20 \%$ of total generation by nuclear, renewable and cross border by 2030 out of 40,000 MW total expected generations (power division, 2014). Renewable energy (RE)technologieswill result in reducing dependency on fossil fuel to a sustainable level and it will ultimately minimize load shed, further expansion of national grid at remote rural areas in Bangladesh. In this regard the Government of Bangladesh has planned to generate $5 \%$ of generation (i.e., $800 \mathrm{MW}$ ) by 2015 and subsequently $10 \%$ (i.e., 2000MW) by 2020 from renewable sources (Power Division, 2014). The average cost of power generation in Bangladesh is approximately $\mathrm{Tk} 6.02 / \mathrm{KWh}$ and diesel based generation is Tk $15.80 / \mathrm{KWh}$, the cost of renewable energy is appears to be pricey with comparison to conventional energy but the difference between conventional and RE is gradually decreasing due to availability of efficient RE technologies (Power Division, 2013). Gradual expansion of RE in rural Bangladesh is getting popularity as the natural resources e.g. gas is depleting with an approximate projection of declining time around 2017 as indicated in Power System Master Plan 2010 (PSMP 2010). With a projection to gradual depletion of fossil fuel resources the developed countries e.g., UK and USA also started exploring alternate energies particularly RE for their sustainable development. The UK has published UK2050 calculator and US State Department also started a program as SE4ALL prior to depletion of their fossil fuel resources. The government of
Bangladesh has also created Sustainable and Renewable Energy Development Authority (SREDA) to implement and disseminate the idea and efficient technology including utilization of RE at rural and urban areas of Bangladesh through scores of program. The power division has published programs, action plans and subsequent master plan in this regard to promote the adoption of RE and energy efficiency programs for demand side management. The government, however, is committed to provide electricity to all citizens by 2021 at a reasonable and affordable price (Power Division, 2013). So, this program is placing as priority on developing RE resources considering the development of off grid electrification program at all level as $40 \%$ of the people of the country live in remote areas which are far away from existing grid line and sometime isolated from the main land. Under the above circumstance, the government has undertaken 500 MW Solar mission (Power Division, 2013) and prospects of wind and hydro which are also under pipeline program. In addition the government has planned to save $10 \%$ of energy by 2015 through implementation of action plan for energy efficiency and conservation and subsequently $15 \%$ by 2021 and $20 \%$ by 2030 at different sectors of power consumption (Power Division, 2014).

\section{Materials and Methods}

The secondary data and to some extent the primary unpublished data has been collected from Power Sector Bangladesh Power Development Board and SREDA. Site visits and discussion with relevant personnel and stakeholders have been made using structured questionnaire (Naki, 1987; Kothari, 1992). The data has been validated, grouped and 
analyzed through using SPSS, Excel and PAST statistical packages where applicable. The subsequent relevant policies of government have been analyzed including Environmental Conservation Act and subsequent rules and guidelines.

\section{Results and Discussion}

\section{Demand supply situation in Bangladesh}

The primary energy resources are mainly biomass and natural gas of which biomass is traditionally used for domestic cooking and small rural industries which is estimated to account for about $73 \%$ of the country's primary energy supply. The country's per capita annual energy consumption was about 167(Kilogram(s) of oil equivalent, unit of energy kgoe (kiligram of oil equivalent) in 2005 which gradually increased at 205 kgoe in 2011(WB Group, 2015).Renewable energy has been a small but rapidly growing sector in Bangladesh economy. Bangladesh's present installed power generation capacity is 11,265 MW (excluding captive and solar) out of that installed capacity the highest generation was recorded to be $7418 \mathrm{MW}$ in July 2014 (Power Division, 2014).

Presently the country faces a peak load shortage of $30 \%$ of total demand. Recent shortage of gas supply resulting in about $10 \%$ of power plants leaving idle. It also reveals that about 1-2\% GDP growth declined annually owing to the scarcity of energy and poorer ability of power generation utilities. The present study seeks to analyze the issues and challenges of RE in Bangladesh with special emphasis on prospects of energy generation at rural areas of Bangladesh and subsequent policy analyses. Attempt has been made to identify the problems and prospects related to the RE at rural areas and possible recommendations for future development.

\section{Different fuels which are used in power generation}

In 2014 around $72 \%$ of total power generation wasbased on natural gas which was around $89 \%$ during 2009. Following is the percentage wise different type of energy consumption for electricity generation including few future projections.

Table1. Comparative table for generation by fuel type

\begin{tabular}{|l|l|l|l|l|l|l|}
\hline Financial Year & $\begin{array}{l}\text { Total } \\
\text { Generation } \\
\text { (Million kWh) }\end{array}$ & $\begin{array}{l}\text { Gas } \\
\text { Based } \\
(\boldsymbol{\%})\end{array}$ & $\begin{array}{l}\text { Coal } \\
\text { Based } \\
(\boldsymbol{\%})\end{array}$ & $\begin{array}{l}\text { Liquid Fuel } \\
\text { Based } \\
(\boldsymbol{\%})\end{array}$ & $\begin{array}{l}\text { Hydro } \\
\text { Based } \\
(\boldsymbol{\%})\end{array}$ & $\begin{array}{l}\text { Imported } \\
\text { power } \\
(\boldsymbol{\%})\end{array}$ \\
\hline $2008-09$ & 26533 & 88.44 & 4.02 & 5.93 & 1.61 & - \\
\hline $2009-10$ & 29247 & 89.21 & 3.53 & 4.76 & 2.50 & - \\
\hline $2010-11$ & 31355 & 82.12 & 2.49 & 12.61 & 2.78 & - \\
\hline $2011-12$ & 35118 & 79.15 & 2.52 & 16.13 & 2.21 & - \\
\hline $2012-13$ & 38229 & 78.12 & 3.02 & 16.51 & 2.34 & - \\
\hline $2013-14$ & 42195 & 72.42 & 2.46 & 18.35 & 1.39 & 5.37 \\
\hline $2015-15$ (Projected) & 47891 & 70.44 & 2.08 & 19.63 & 1.68 & 6.17 \\
\hline $2016-17$ (Projected) & 53600 & 72.41 & 1.78 & 17.60 & 1.31 & 6.90 \\
\hline
\end{tabular}

Source: Power Division, 2014

The power sector, industries, commercial, agriculture and other sectors are suffering from shortage of energies and powerwhich are also gradually increasing with the pace of growing demand. The unmet demand are also gradually increasing as the country's GDP is being projected more than $6 \%$ per year to achieve the status of the country as middle income ranked in global aspect. Overall the domestic gas demand forecast by each sector is clearly defined in Fig. 1 to understand the energy scenario in near future. The comparative regression analysis for the analyzed parameters e.g. power, captive, fertilizer, industrial, commercial, domestic, CNG, tea estate and unmet plus potential demand as of June 2010 is projected in the Table 1. Throughregression analysis the outcome was found to be linear which is depicted in Fig. 1 and Table 2. The value of $\mathrm{R}^{2}$ for the utilization of $\mathrm{CNG}$ was recorded to be highest, and the commercial, captive, domestic, industries, fertilizer and power sector are ranked towards lower regression, respectively.

Table 2. Comparative regression analysis for year wise gas demand forecast at different sector in 2008-09 to 2013-14 and projected at 2014-15 to 2016-17

\begin{tabular}{|l|l|l|}
\hline Parameters & $\begin{array}{l}\text { Regression } \\
\text { Equation }\end{array}$ & $\begin{array}{l}\text { Regression } \\
\text { values }\end{array}$ \\
\hline Power & $\mathrm{Y}=29.68 \mathrm{x}-58541$ & $\mathrm{R}^{2}=0.205$ \\
\hline Fertilizer & $\mathrm{Y}=6.652 \mathrm{x}-13097$ & $\mathrm{R}^{2}=0.704$ \\
\hline Industries & $\mathrm{Y}=111.1 \mathrm{x}-22322$ & $\mathrm{R}^{2}=0.860$ \\
\hline Domestic & $\mathrm{Y}=78.69 \mathrm{x}-15791$ & $\mathrm{R}^{2}=0.905$ \\
\hline Captive & $\mathrm{Y}=25.29 \mathrm{x}-50586$ & $\mathrm{R}^{2}=0.973$ \\
\hline CNG & $\mathrm{Y}=12.35 \mathrm{x}-24747$ & $\mathrm{R}^{2}=0.980$ \\
\hline Commercial & $\mathrm{Y}=1.879 \mathrm{x}-3758$ & $\mathrm{R}^{2}=0.978$ \\
\hline Tea Estate & $\mathrm{Y}=2$ & $\mathrm{R}^{2}=\# \mathrm{NA}$ \\
\hline $\begin{array}{l}\text { Unmet } \\
\text { Potential }\end{array}$ & $\mathrm{Y}=12.58 \mathrm{x}-25657$ & $\mathrm{R}^{2}=0.022$ \\
\hline
\end{tabular}




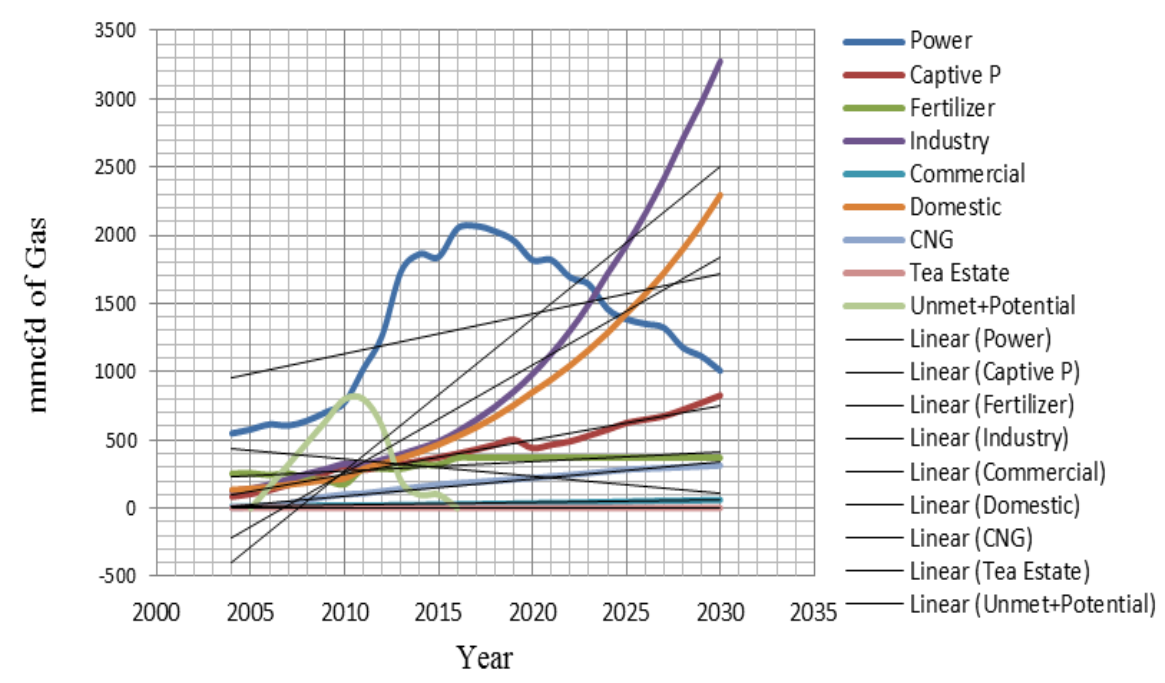

Fig. 1. Year wise gas demandforecast by sectorwise in mmcfd; PSMP 2010

The unmet potential has relatively weak regression response in this regard. The unmet and potential demand of gas in Bangladesh has been graphed in the following Fig.2. Among the following components e.g. CNG, domestic, industry, fertilizer, captive, potential, power and others, the power sector is facing highest unmet demand in Bangladesh.

\section{Prospects of RE in Bangladesh context}

Natural gas is used for generation of electricity, production of fertilizer, industrial uses, cooking at domestic and commercial utilities including plying motor of vehicles. The country also has coal reserves which are yet to be explored. Per capita generation (including captive) increased from 225 MW in 2008 to $292 \mathrm{MW}$ in 2012. Moreover access to electricity has also increased from 45 percent in 2008 to 60 percent in 2012 and $68 \%$ in 2014 (Power Division, 2014). Owing to the gradual depletion of natural energy resources the government has taken scores of initiative to adopt $\mathrm{RE}$ at the off grid rural and remote areas in Bangladesh to meet the unmet demand. Among the potential possible sources of RE (Solar energy), the solar Energy has highest potential in Bangladesh. According to the map of global horizontal irradiance, based on the measured data, theoretical model and satellite image derived data shows that monthly average solar global radiation in Bangladesh is around $4.255 \mathrm{KWhm}^{-2} \mathrm{day}^{-1}$ and wind speed at the coastal area is around $4.5 \mathrm{~ms}^{-}$ ${ }^{1}$ (BRE report, 2007). Which indicates that Bangladesh is having abundant scopes of solar energy due to its position in the sphere (Figure 3 and 4).

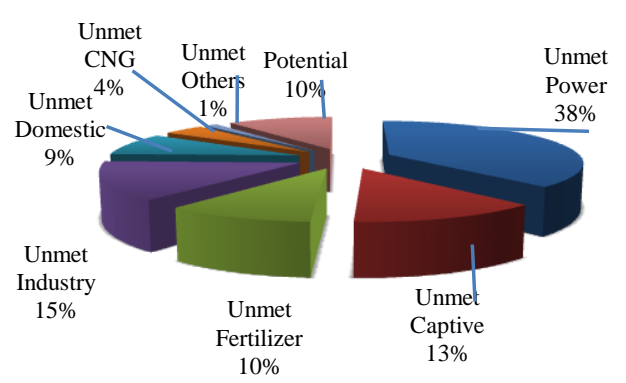

Fig. 2. Unmet and potential demand in mmcfd as of June 2010 (Petrobangla)

According to the government policy on RE the Rural Electrification Board (REB) has started installation of the PV-based 806 Solar Home Systems (SHSs) under the French financial assistance which was named as "Diffusion of Renewable Energy Technologies" as Pilot Project. In which 3 battery charging stations with a total capacity of $29.4 \mathrm{KWph}$ (kilo watt per hour) and a number of standalone SHSs with a total capacity of $32.6 \mathrm{~kW}$ phas been installed in rural areas for the private owners through monthly pay back system. At the end of 2009, the REB has installed 14,000 SHSs in 18 rural utilities (known as Pally BidyutSamity or PBSs) with more than 138,000 households registered for future SHS installations. The use of solar energy is becoming a potential source due to its global position between 20.30 and 26.38 degrees north latitude and 88.04 and 92.44 degrees east for efficient solar energy utilization (Hasan et al., 2010). The hours of sunlight each day throughout the year is shown in the following Figure-3 (Shariar et al., 2011). The highest and the lowest intensity of direct radiation in $\mathrm{W} / \mathrm{m}^{2}$ are also shown in the Figure-4 (Shahriar et al., 2011).In recent study conducted by Renewable Energy Research Centre, it was found that average solar 
radiation varies between 4 to $6.5 \mathrm{kWh} / \mathrm{m}^{2}$ day ${ }^{-1}$ and maximum amounts of radiation are available in the month of March-April and minimum in December-January (Hasan et al., 2010). People residing at remote areas of Bangladesh usually pay one of the highest rates for electricity from diesel generated micro-grids. One specific survey at Sandwip under Chittagong district showed that most of the commercial enterprises namely; Enam Nahar market were using diesel micro-grid services. Depending on the type of appliance being used, daily rates being converted to tariff which ranged from BDTk 46/kWh to BD Tk $76 / \mathrm{kWh}$ due to high demand of electricity for commercial activities at that market and the consumers was paying that high tariff on a daily basis without any contractual commitment to the entrepreneur including without assurance of quality and services.

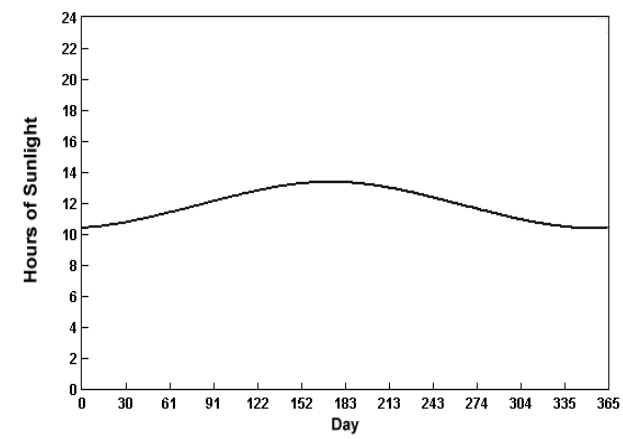

Fig. 3. The amount of hours of Sunlight in Bangladesh

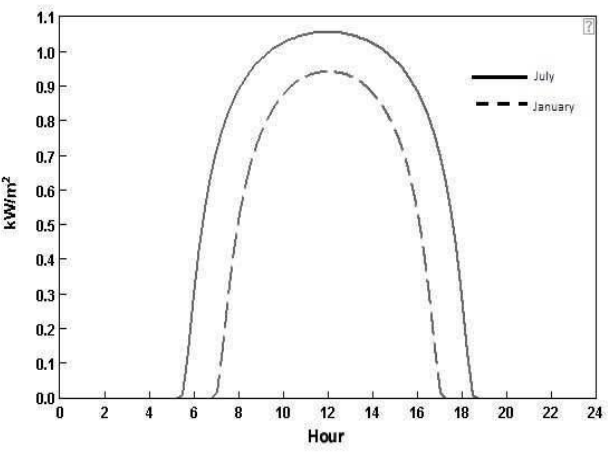

Fig. 4. The highest and the lowest intensity of direct radiation in $\mathrm{Wm}^{-2}$

At that area before establishing solar mini-grid a preliminary survey was conducted which suggested that the potential consumers of a solar mini grid in Enam Nahar market were eager to pay an equivalent amount to cover their cost of service, considering its reliability and scope of modernization with alternative energy. Based upon tariff prior to solar electrification, financial analysis and project financing criteria of IDCOL, a private utility company Purobi Green Energy Limited (PGEL) set the tariff at Tk $32 \mathrm{kWh}^{-1}$.

Subsequently PGEL has invested in the nation's first commercial solar mini-grid at the coastal island of Sandwip in September 2010, with financing from Infra Structure Development Company Limited (IDCOL) for a solar plant of 100
$\mathrm{kW}$ solar PV coupled to a $40 \mathrm{~kW}$ diesel backup having $220 \mathrm{~V}$ AC mini-grid with a view to keep an affordable tariff along with service hours from 9 am to $11 \mathrm{pm}$ for retaining sustainable revenue and financial viability. For implementation of this project approximately 1500 square meters was required at that area. Since October 2010, the solar mini-grid of PGEL has been serving the Enam Nahar market for various appliances used on a daily basis and to date, the plant has generated more than $320 \mathrm{MWh}$ with a specific capacity of $80.52 \mathrm{kWh} / \mathrm{kWp}$, displacing 222,230 kg of $\mathrm{CO}_{2}$ (Khan and Haque, 2014).Eventually to harness the RE particularly implementation and use of the followingoptions may be taken under consideration at rural and remote areas e.g.,

(i) Solar cooker

(ii) Solar irrigation system

(iii) Solar lantern

(iv) Solar home systems

(i) Solar cooker: Reduction of carbon emission and reducing the dependency on fossil fuel, solar cooker can compensate the use of natural gas to some extent and this amount of natural gas can be utilized in heavy industries as emphasized by the government to reduce ultimate energypower consumption at rural and urban houses.

(ii) Solar irrigation: The solar irrigation system: nearly $35 \%$ of its GDP and employment over $60 \%$ are based on agriculture. The country annually consumes over 3.7 million tons of imported crude and finished petroleum products, out of which about 2.5 million tons is high speed diesel (HSD). This mid-distillate is a deficit product, over $35 \%$ of which is used in the agriculture sector, to operate over 1.5 million tons of HSD based low lift pumps, shallow tube wells and deep tube wells. There are 250,000 electric irrigation pumps mostly under REB. This huge fossil fuel based energy may be replaced by solar powered irrigation pumps.

In addition during 2004, the first large scale pilot project on solar PV pumps were established at four "eco-villages" at Barind Tracts. Each PV Pump was used to lift water 10,000liters per day to overhead water tanks for storage and supply of drinking water for 40 families. The success of this demonstration was replicated with 7 solar irrigation pumps that have been commercially installed by public and private organizations in a number of different locations. In addition, 10 solar drinking water pumps with each capacity of 20,000-50,000 liters per day are to be installed by GTZ in CIDR (severe storm) affected area in the southern part of the country. An estimated 200,000 CIDR affected people will be benefited from safe drinking water supplies by this project.REB has also undertaken a project "Introduction of Solar Powered Irrigation Pump as well as Power Management and 
Distribution System to Mitigate Energy Crisis and Climate Change" that was funded by Climate Change Trust Fund under Ministry of Environment and Forest. Under this program, 20 solar irrigation pumps will be installed. Another 20 solar irrigation pumps will be installed at different PBSs by REB under KOICA (Korea) funding.

(iii) Solar lantern: Lower income households' kerosene lanterns for lighting may also be replaced by more safe and environment friendly solar LED lanterns. A pilot project to disseminate solar LED lanterns has been started with the assistance of development partners. The project will reduce $\mathrm{CO}_{2}$ emissions by more than 0.8 million tons per year.

Through collaboration effort of five partners, IDCOL, Donor Agencies, NGO's/ Micro Financing Institute (MFI) or Partner Organizations, Manufacturers/ Suppliers and Professionals approximately 30,000 systems are being installed per month which are adding 1.5 MW to power generation and 150,000 people will get opportunity of access to electricity. However to accelerate the Government initiative on renewable energy Bangladesh Bankproviding soft loan with lower interest rate to the consumers and manufacturers for investment in this sector.

(iv)Solarhome systems: Since 1996, market penetration of SHSs has increased primarily due to the efforts of NGOs. Grameen Shakti, one of the Bangladesh's largest NGOs, sells PV systems on credit schemes to rural households through its extensive network. Another 21 NGOs are also engaged in promoting PV technology in Bangladesh such as Rural Services Foundation (RSF), BRAC, Bright Green Energy Foundation (BGEF), CMES, Srijony Bangladesh, Ingen, IDF, and TMSS. PV modules are generally imported with a few private companies manufacturing PV accessories such as batteries, charge controllers, and inverters.

According to World Bank market survey, the market size for Solar Home Systems (SHSs) is 500,000 households, mainly located in off-grid areas and islands of Bangladesh (World Bank, 1998).This assessment was based on current expenditure levels on fuel for lighting and battery charging being substituted by SHS (World Bank, 1998). These studies have revealed that households in most developing countries typically do not spend more than $5 \%$ of their income on lighting and use of small appliances.By this measure, 4.8 million rural households could pay for a solar home system (World Bank, 1998).However, recent market trends indicate large demand for solar PV technology in rural areas due to slow expansion of grid power, lack of uninterrupted power supply, declining cost of solar technology and increased power demand of rural households. With the penetration rate of television and mobile phones in rural areas having reached 56\%, solar PV system suppliers expect their market will be expanded up to 75 million people if appropriate fiscal and regulatory measures are taken.

At present, the national grid is only serving $50 \%$ of the estimated 10,000 rural markets and commercial centers in the country that serve as excellent markets for centralized solar photovoltaic plants. Currently, private diesel generator operators are serving most of the off-grid rural markets, this includes government administrative offices, NGOs, health centers, schools, banks, and police stations. These facilities have separate budgets for fuel and could easily be retrofitted with solar photovoltaic applications.Over $80 \%$ of the private diesel operators are also interested in marketing SHS in surrounding areas if favorable financing arrangements were available.

\section{Cost analysis for power generation}

Unit generation cost, the levelized energy cost (LEC, also known as levelized cost of energy, abbreviated as LCOE) was estimated using the following equation (Branker et al., 2011) to determine the cost of electricity generation from a specific source to break even over the lifetime of the project. In this analysis initial investment, operations and maintenance, cost of fuel, cost of capital over the plant life has been taken under consideration to calculate the costs of generation in US context which may also be used in Bangladesh context through customization of few observations.

Where,

$$
\mathrm{LEC}=\frac{\sum_{t=1}^{n} \frac{I_{t}+M_{t}+F_{t}}{(1+r)^{t}}}{\sum_{t=1}^{n} \frac{E_{t}}{(1+r)^{t}}}
$$

$L E C=$ Average lifetime levelized electricity generation cost

$I_{t}=$ Investment expenditures in the year $t$

$M_{t}=$ Operations and maintenance expenditures in the year $t$

$F_{t}=$ Fuel expenditures in the year $t$

$E_{t}=$ Electricity generation in the year $t$

$r=$ Discount rate

$n=$ Life of the system

The assumptions of capacity factor have significant impact on the calculation of LCOE. For example, Solar PV may have a capacity factor as low as $10 \%$ depending on location (Branker et al., 2011).

The above figures incorporate tax breaks for the various forms of power plants and subsidies range from $0 \%$ (for Coal) to $14 \%$ (for nuclear) to over $100 \%$ (for solar).In Bangladesh context, the Renewable Energy (RE) program has not been included in PSMP 2010, but in later stage different types of programs have been adopted by Power 
Division in a sustainable and cost effective wayincluding the possibility of adoption and diffusion of RE program at remote off grid areas.

In Bangladesh, various solar issues still remain unanswered and the ownership of the energy discussion is mostly still on rural energy access.Experts encourage that rural energy discussions must move hand-in-hand with a green energy and technology with projection of real demand, which will attract sustainable investments and key global players to finally propel solar forward in rural areas in Bangladesh. For implementation of RE program there need to be effective engagement of the various commercial industries and better penetration of rural energy access with increasingly attractive solar economics and supportive good governance to harness and put into practice and explore the immense solar potential in rural remote areas. Better PV technologies may also lead to clean, resilient, economical and dependable source of energy at off grid areas of Bangladesh. The management of new and used batteries including used solar panel as a whole is yet to be given emphasis to avoid sudden environmental disaster in near future.

\section{Renewable Energy Development for Climate Change Mitigation under Bangladesh Climate Change Strategy and Action Plan 2008 (BCCSAP)}

The role of Bangladesh to greenhouse gas (GHG) emissions is miniscule. In 2005, Bangladesh emitted 45 to 53 million tones $\mathrm{CO}_{2}$ less than $0.2 \%$ of the World'stotal. Notwithstanding Bangladesh's minuscule contribution to GHG emissions, but climate change effects will significantly impact on Bangladesh and the country has limited financial ability to mitigate those challenges.Despite, the Bangladesh Government's strong commitment toplay its part in reducing emissionsnowand in the future. Bangladesh Climate Change Strategy and Action Plan (BCCSAP) are built on six pillars e.g., Food security, social protection and health, comprehensive disaster management, Infrastructure development, research and knowledge management, mitigation and low-carbon development, and Capacity building and institutional development. Renewable Energy development falls under 'Climate Change Mitigation' measures which is delineated as $5^{\text {th }}$ pillar (Mitigation and low carbon development) of BCCSAP.

According to Kyoto Protocol in 1997, the developed countries are also focusing more on reducing their reliance on the fossil fuel including use of conventional energy. In this regard, the Infrastructure Development Company Limited (IDCOL), a Government owned public limited financial institution providing long term financing to private sector infrastructure projects and renewable energy projects to promote renewable energy business in Bangladesh on commercial basis. Under which, the programs encourage microfinancing and income generation activities focusing on IDA, GEF program which started as a key component of the rural electrification and renewable energy projects assisted by World Bank.

Now IDCOL is largely involved with Solar Home Systems (SHSs) distribution financing activities. The program is being implemented through the Partner Organizations (POs). The role of PO is to select the project areas and potential customers, extend loans, install the systems and provide the maintenance support. The initial target of installing 50,000 SHS was achieved through 15 partner organizations in August 2005, three years before targeted date of completion. Following the success, IDA, GTZ, KfW, ADB and IDB have extended their support and IDCOL has revised its target to distribute 1 million SHS by 2012. Since August 2010 partner organizations of IDCOL distributed 645,000 (30 MW) SHS throughout the country benefiting over 6 million rural people, which has contributed to approximately $22000 \mathrm{tCO}_{2}$ emission reduction per annum.

Solar home system provided reliable power for lighting and operating low powered appliances such as radio, television, small electric fans. The electricity provided by a SHS are also being used to run DC driven equipment's such as DC soldering irons, drilling machines etc. and to charge the battery of mobile phones. In addition the larger systems are capable to run computers, refrigerators, pumps etc.

A rural family can have bright light through avoiding kerosene fumes and fire-risk to improve the health of children, woman and other members of the house. In one study it was found that, middle income family can saves around BD Tk 800.00 for kerosene per month through installation of a solar home system (SHS) and subsequently low income generated family can save around BD Tk 200.00 per month. SHS allow women to take part at home based income generating activities such as poultry rearing, handicraft weaving, etc. Children can also study under bright light and get connected to the outside world through televisions, internets and mobile phones etc.

Rural business hours including income turn-over will likely be increased. Over 5000 rural woman are working atvillage based Technology Centreto assemble and repair solar accessories such as charge controllers, mobile phones charges, invertors etc. rural health clinic can be brought under this SSH to operate its electronic equipment used to check patients. On an average a solar home system can replace half a ton of carbon annually. By this time, installed SHSs in Bangladesh are reducing more than 300,000 ton carbon annually. 


\begin{abstract}
National energy policies
Policy reviews

The National Energy Policy of Bangladesh acknowledges the issue of energy security by addressing following policy objectives:to provide energy for sustainable economic growth so that the economic development activities of different sectors are not constrained from energy shortages; to meet the energy needs of different zones of the country and socio-economic groups. Bangladesh is trying to get out of its dependency on gas by introducing fuel mix and diversifying sources of supply. Thus liquid fuel, coal and nuclear energy are emerging as new sources. Although renewable energy is not well developed and reported to be expensive. Recently the Government of Bangladesh has identified the RE as a potential source for sustainable energy security giving emphasis at on \&off grid areas, the strategy is toembracerenewableenergymore comprehensively through offering appropriate technology at affordable manner.
\end{abstract}

\section{Renewable energy policies}

Government has approved Renewable Energy Policy in 2008 which became effective from 2009. The objectives of the Policies are to: Harness the potential of renewable energy resources and dissemination of renewable energy technologies in rural, peri-urban and urban areas; Enable, encourage and facilitate both public and private sector investment in renewable energy projects;Develop sustainable energy supplies to substitute indigenous non- renewable energy supplies;Scale up contributions of renewable energy to electricity productions;Scale up contributions of renewable energy both to electricity and heat energy;Promote appropriate, efficient, and environment friendly use of renewable energy;Train, facilitate the use of renewable energy at every level of energy usage;Create enabling environment and legal support to encourage the use of renewable energy; Promote development of local technology in the field of renewable energy and promote clean energy towards implementation of CDM program.

\section{RE programs}

The government of Bangladesh planned to reduce the dependency on fossil fuel through diffusion of renewable energy mainly at rural areas of Bangladesh. Under that circumstances the government of Bangladesh has created Sustainable and Renewable Energy Development Authority (SREDA) Act 2012 which looks after the implementation and dissemination of RE at all levels with all logical supports to the investors in this field. As part of this RE program the following plans have been taken under consideration (Power
Division 2014): Plan to generate $800 \mathrm{MW}$ from RE sources; Road map for generation of 500 MW from Solar Energy Sources; 160 MW generation from wind sources; Wind Mapping program at 12 locations in Bangladesh; Approval of SREDA Act 2012 and establishment of SREDA; 404 MW generation from RE; Establishment of 33 lakhs Solar Home System; Within 2017 aim to install 60 lakhs Solar Home System (SHS); Sequentially Establishment of 193 Solar Irrigation Pump by replacing Diesel irrigation pump; Planning to implement 10 Mini Grid projects and by 2017 plan to implement 50 projects, respectively.

To combat the global climate change issues the following program has been taken by SREDA which is due to be implemented during 2015-2016 and onward; Solar 500MW, wind $15 \mathrm{MW}$, Biomass and biogas 10, hydro power 250MW, others 25 with a total of $800 \mathrm{MW}$. Through SREDA the government also has taken few initiatives in commercial and social areas which are as follows:

\section{Commercial projects}

Non arable land will be taken under RE program under non-government management through Build, Own and Operate (BOO) and establishment of Solar Park. Electrification at off-grid area establishment of mini-grid through Remote Area Power Supply System (RAPSS).Establishment of Solar System at Personal and commercial building.Introduction of Solar panel and system at industries.Replacement of diesel operated pump bysolar operated pump. Establishment of Solar project on the roof top of semi-government and government buildings.

\section{Social projects}

Rural Health Complex: Establishment of Solar Panel having 50MW Capacity. Educational Institution at Hard to reach area: Establishment of Solar Panel having 40MW Capacity. Union Information Service Center: Establishment of Solar Panel having 07MWCapacity. Religious Institution having no electricity connection: Establishment of Solar Panel having 12MW Capacity. Remote Railway Station: Establishment of Solar Panel having 10MW Capacity. Government offices at off grid area: Establishment of Solar Panel having 40MW Capacity.

In Bangladesh, government utilities are mainly involved for development of large scale grid connected renewable energy based power plant project, subsequently the private sectors are also involved at off-grid home-based renewable energy solutions. By this time the following progress has been made in RE sector in Bangladesh (Power Division, 2014) which is depicted in the following tabular form (Table 3). 
Table 3. The implemented RE in Bangladesh.

\begin{tabular}{|c|l|c|}
\hline Sl. no & \multicolumn{1}{|c|}{ Category } & Achievement (2014) \\
\hline 1 & Solar Home System (3.3 million) & $150 \mathrm{MW}$ \\
\hline 2 & Solar System at roof top of Govt./non govt. building & $03 \mathrm{MW}$ \\
\hline 3 & Solar System at Commercial building and shopping mall & $01 \mathrm{MW}$ \\
\hline 4 & Solar PV for new connection at roof top of buildings & $11 \mathrm{MW}$ \\
\hline 5 & Solar Irrigation (193) & $01 \mathrm{MW}$ \\
\hline 6 & Wind based power generation & $02 \mathrm{MW}$ \\
\hline 7 & Bio-mass based power generation & $01 \mathrm{MW}$ \\
\hline 8 & Bio-gas based power generation & $05 \mathrm{MW}$ \\
\hline 9 & Hydro Power $\quad$ Total & $230 \mathrm{MW}$ \\
\hline
\end{tabular}

Policy analysis

Bangladesh faces numerous challenges for renewable energy development that includes the following:

\section{Financial hurdles}

High initial capital costs and lengthy rate of return needs to be rationalized in RE policy.Financing mechanisms needs to be incorporated in RE Policy. Incorporation of investment incentives in $\mathrm{RE}$ policy.Regulatory support for market oriented RE programs and introduction of feed-in tariff structure where applicable.

\section{Technical hurdles}

Incorporation of standards and quality control (Star Labeling) for RE equipment.RE grid operations/ $\mathrm{RE}$ grid code needs to be incorporated in the RE policy.Incorporation and promotion for manufacturing RE equipment in policy frame work.Proper management and disposal of unused and used RE equipment and wastes needs to be included in RE policy or in RE guideline.Inclusion of $\mathrm{RE}$ expansion program in policy to delineate national grid and off grid area to promote expansion of RE.Inclusion of monitoring and evaluation of RE program in policy/rules/guideline.

\section{Incentive in $R E$ marketing}

Installation costs at the end user level needs to be incentivized.Guidelines need to be incorporated to control and manage market mechanism for trading of RE equipment through providing proper licensed vender.

\section{Access to information}

Awareness program on renewable energy resources, technical/economic information about REs, equipment suppliers, and potential financiers need to be incorporated in policy for expansion and utilization of RE in private, public, industry, utility, financial institutions.Incorporation of Energy Efficiency and Energy Conservation including promotion of $\mathrm{RE}$ at remote and off grid rural areas.Provision of close coordination among the government and renewable energy development entities and others.

\section{Conclusions}

Lessening of dependency on imported solar panels through establishment of local industries having assembling facilities of good durable materials is of deem necessary for further operation and maintenance of RE at rural areas.

In addition, soft loan for the poor and ultra-poor residents at rural areas using initiative through different developmental mechanism with rational incentive for off grid consumers'upon their total consumed power with comparison to the subsidy given to the national grid users. Subsequently energy efficiency program could also be implemented in this regard. The development partner e.g. World Bank, Asian Development Bank, gtz, KfW and so forth may also be taken on board for ultimate development of RE expansion.

Solar power generation (photovoltaic, solar thermal) is estimated to have enormous potential (David, 2011), the solar power generation cost at this point is more than five times higher than the power generation cost by conventional power generation. Cost minimization through adoption of new technologies is required for wide spread acceptance at rural areas. Toscale up the large-scale introduction of solar power generationa comprehensive and sustainable incentive arerequired to be distributed atvarious levels and forms.

To attract Private Power Producers incentives and subsequent possible tariff adjustment is of deem necessary where applicable.Regular updates and data availability for RE implementation generation scenarios at website of power sector to understand unmet demand and their management at different levels.

Under the above circumstances, it is to be further investigated through research and piloting the possibility of exploration and implementation opportunities to utilizesolar energy as renewable energy by 2030 to explore the management and possibility RE generation for unmet demand. It also reveals from the practical outcome that the target projected for implementation of RE Policy is yet to 
be achieved. In addition if the imported electricity proposed from similar natured projects from neighboring countries may also be taken under consideration to full fill the target of $10 \%$ of total electricity demand by renewable energy by 2020 .

UK and USA also started exploring alternate energies particularly from REsfor their sustainable development, successively UK has published UK2050 calculator and US State Department also started a program as SE4ALL prior to depletion of conventional energy resources. The government of Bangladesh has rightfully created SREDA to implement and disseminate the idea and technology at rural and urban areas of Bangladesh through scores of program as the natural resources are

\section{References}

Bangladesh Renewable Energy Report. 2007, Asian and Pacific Centre for Transfer of Technology Of the United Nations - Economic and Social Commission for Asia and the Pacific (APCTT-UNESCAP) This report was prepared by Prof. Dr. Neem Chandra Bhowmik, Director Renewable Energy Research Centre, University of Dhaka (Phone 9677125, 9661900/4570, Email: rercdu@yahoo.com) under a consultancy assignment given by the Asian and Pacific Centre for Transfer of Technology (APCTT).

Branker, K.; Pathak, M. J. M. and Pearce, J. M. 2011."A Review of Solar Photovoltaic Levelized Cost of Electricity", Renewable \& Sustainable Energy Reviews, 15, pp.44704482.

California Energy Commission, 2007. A Review of Electricity Unit Cost Estimates Working Paper, December 2006 - Updated May 2007.

David, J. and MacKay, C.2011. Sustainable Energy - Without the hot air, UIT Cambridge, England.

Hasan, F.; Hossain, Z.; Rahman, M. and Rahman, S.A. 2010."Design and Development of a Cost Effective Urban Residential Solar PV System", December 2010. Available at: http://dspace.bracu.ac.bd/bitstream/handle/103 61/1467/Final\%20Report.

Khan, J. H. and Haque, A. 2014. The First minigrid service in Bangladesh, published in the Daily New Age, February 9, 2015. depleting with an approximate projection of declining time at around 2017 (PSMP 2010). The Power Division has published programs and action plans and subsequent master plan in this regard to promote the adoption of Renewable Energy and Energy Efficiency programs in the course of demand side management.The renewable technologies reflect the Climate Change and energy conservation issues, which is now a great concern for the developed and developing nations. Still many unexplored thoughts, ideas and appropriate policies including development of institutional arrangement may help for the sustainable development towards achievement of millennium goal.

Kothari, C. R. 1992.Research Methodology, Methods and Techniques, $2^{\text {nd }}$ Edition. Willey Eastern Limited, New Delhi, 110002.

Naki, S. A. 1987.Instruction of Assessment of Socio-economic Survey. ( $1^{\text {st }}$ Edition), Mohiuddin Ahmed, The University Press Limited, Red Cross Building, 114 Motijheel, Commercial Area, Sanghshaptak Publisher, 19 Sheikh Shaheb Bazar Dhaka, Bangladesh.

Power Division, 2013. 500MW Solar Program (2012-2016). An initiative to promote renewable energy program in Bangladesh. Power Division, Ministry of Power Energy and Mineral Resources, Government of the People's Republic of Bangladesh.

Power Division, 2014. Alokito Bangladesh. "Success in power sector during five years (2009-2014)".Power Division, Ministry of Power Energy Mineral Resources, the People's Republic of Bangladesh.

PSMP (Power System Master Plan). 2010. Bangladesh 2030 Vision, Long Term Power Development Strategy. TEPCO, Japan and Power Division, Ministry of Power Energy and Mineral Resources.

Shariar, K. F.; Ovy, E. G. andHossainy, K. T. A. 2011. Closed Environment Design of Solar Collector Trough using lenss and reflectors. World Renewable Energy Congress 2011, Sweden. 